\title{
Long-Term Effect of Manure and Fertilizers on Soil Physico-Chemical and Chemical Properties in Rainfed Groundnut Growing Alfisols
}

\author{
C. Shivashankar*, A. Prasanthi, K. V. Naga Madhuri and N. Sunitha \\ Department of Soil Science \& Agricultural Chemistry, S. V. Agricultural College, Tirupathi, \\ Angrau, (A.P.), India \\ *Corresponding author
}

\begin{tabular}{|c|}
\hline Key v \\
\hline $\begin{array}{l}\text { Manure and } \\
\text { Fertilizers, Soil } \\
\text { Physico-Chemical and } \\
\text { Chemical Properties }\end{array}$ \\
\hline Article Info \\
\hline $\begin{array}{l}\text { Accepted: } \\
18 \text { May } 2018 \\
\text { Available Online: } \\
10 \text { June } 2018\end{array}$ \\
\hline
\end{tabular}

A B S T R A C T
A long-term field experiment was started at the Regional Agricultural Research Station, Tirupati of Acharya N.G. Ranga Agricultural University during kharif-1981. The present study was undertaken during kharif-2015 with a prime objective of monitoring the changes in concentration over a period of time. The soil of the experimental field was red sandy loam (Haplustalf). The experiment has eleven treatments each replicated four times in a randomized block design. The $\mathrm{pH}, \mathrm{EC}$ and organic carbon of the soil was not significantly influenced by different treatments in both the surface and subsurface soil.The free calcium carbonate of surface soil was significantly influenced by different treatments whereas sub surface soil was not significantly influenced by different treatments. The available $\mathrm{N}$ of surface soil was ranged from140.3 to 184.6 with a mean value of 165.0. However, highest significant value was recorded in FYM alone treated plot $\left(\mathrm{T}_{2}\right)$ (184.6). Available P, K, content of the soil decreased in all the treatments studied as compared to its initial status of $\mathrm{P}\left(20.2 \mathrm{~kg} \mathrm{ha}^{-1}\right)$ in both the surface and subsurface soil. The exchangeable calcium of surface soil was ranged from 2.32 to 4.39 with a mean value of 3.37 . The exchangeable magnesium in surface soil ranged from 1.80 to 2.74 .

\section{Introduction}

Groundnut, (Arachis hypogaea L.) is the premier oilseed crop of India mainly grown under rainfed conditions as a sole crop and intercrop during kharif and rabi seasons. During the year 2014-15 there was a production of 6.68 million tons of groundnut from an area of 4.19 million ha with an average yield of $1591 \mathrm{~kg} \mathrm{ha}^{-1}$ in India (Directorate of Groundnut Research, Junagadh). Globally, India ranks first in area, fifth in terms of productivity and second in production after China. Though India occupies a unique position with respect to area as well as production, the average production and yield per ha of groundnut is comparatively very low.

Long-term fertility experiments provide valuable information on impact of continuous use of fertilizers with organics and varying combinations of inorganics on soil fertility and crop productivity and become good platform for monitoring the changes in soil fertility and productivity. These long-term studies are 
important for examination and quantification of cultivation based changes in agro-ecosystems and enables the evaluation of effect of continuous fertilizer application on different nutrient concentrations in soil. Long-term fertilizers trial on groundnut has been conducting since 34 years at Regional Agricultural Research Station, Tirupati. Hence the present investigation was undertaken to study the long-term effect of manure and fertilizers on soil physico-chemical and chemical properties in rainfed groundnut growing alfisols with test crop groundnut, Dharani variety.

\section{Materials and Methods}

Soil samples were collected at sowing of the crop at two depths i.e., 0-15 and 15-30 cm. soil $\mathrm{pH}, \mathrm{EC}$ and organic carbon were determined by Jackson(1973), Richards et al., (1954) and Walkley and Black wet oxidation method (1934).The free calcium carbonate content of the soil was determined from Piper, (1966). The available nitrogen was determined by alkaline permanganate method (Subbaiah and Asija 1956), phosphorus by Bray and Kurtz (1954) and available potassium by Jackson (1973).Exchangeable calcium and magnesium were determined by following versenate titration method (Vogel, 1978) and expressed as cmol $(\mathrm{p}+) \mathrm{kg}^{-1}$ of soil. Data was analyzed statistically for test of significance following the Fisher's method of analysis of variance as outlined by Panse and Sukhatme (1985).

\section{Results and Discussion}

\section{Physico-chemical properties}

\section{Soil pH}

The $\mathrm{pH}$ of the soil was not influenced by different treatments in both the surface and subsurface soil. The $\mathrm{pH}$ of the surface soil ranged from 5.24 to 5.61 . The highest value was recorded in control $\left(\mathrm{T}_{1}\right)$ (5.61) followed by FYM alone $\left(\mathrm{T}_{2}\right)(5.57)$ whereas the lowest value was recorded in NPK treated plot $\left(\mathrm{T}_{8}\right)$ (5.24). The $\mathrm{pH}$ of the subsurface soil ranged from 5.22 to 5.50. The highest value was recorded in control plot $\left(\mathrm{T}_{1}\right)$ (5.50) whereas the lowest was observed in NPK treated plot $\left(\mathrm{T}_{8}\right)$ (5.22). A slight decrease in soil $\mathrm{pH}$ was observed (Table1) in all the treatments studied with surface and subsurface soil as compared to the initial soil $\mathrm{pH}$ (6.7) studied during the starting of this experiment in the year 1981. The trend of little variation with respect to $\mathrm{pH}$ in the surface and sub-surface soil among manurial and fertilizer treated plots might be due to the acidifying effect of different fertilizer combinations and FYM alone.This was supported by the findings of Urkurkar et al., (2010), Hemalatha and Chellamuthu (2013) and Brar et al., (2015).

\section{Electrical conductivity}

The EC of the soil was not significantly influenced by different treatments in the surface and subsurface soil. The EC of surface soil ranged from 0.04 to 0.19 and subsurface ranged from 0.04 to $0.09 \mathrm{dS} \mathrm{m}^{-1}$. The highest was recorded in gypsum alone treatment plot $\left(\mathrm{T}_{6}\right)(0.19)$ and the lowest value was recorded in the treatment $\mathrm{P}$ alone treatment plot $\left(\mathrm{T}_{4}\right)$ (0.04). The soil is said to be normal in soluble salt content as per the limit suggested by Lakshmi et al., (2013). The trend of variation of EC of the soil between the treatments in both the soil layers was almost negligible and statistically non-significant. This was supported by Bhaskar et al., (1992) and Brar et al., (2015).

\section{Soil organic carbon}

The organic carbon content of surface soil ranged from 0.28 to 0.53 . However, the highest value was observed in FYM alone 
treated plot $\left(\mathrm{T}_{2}\right)(0.53)$ followed by $\mathrm{T}_{3}(0.40)$ and $\mathrm{T}_{1} \quad(0.39)$ whereas the lowest was observed in $\mathrm{K}$ alone treated plot $\mathrm{T}_{5}(0.28)$. With regard to the sub surface soil, the organic carbon ranged from 0.25 to 0.31 . However, the highest value was observed in NPK $+\mathrm{L}$ $\left(\mathrm{T}_{10}\right)(0.31)$ whereas the lowest value was observed in $\mathrm{P}$ alone treated plot $\left(\mathrm{T}_{4}\right)(0.25)$ and $\mathrm{K}$ alone treated plot $\left(\mathrm{T}_{5}\right)(0.25)$. The soil organic carbon content did not influenced by the different treatments in both the surface and sub-surface soil.

However, numerical differences were observed among the different fertilizer combinations and FYM alone in the surface and sub-surface soil. the accumulation of organic matter in the surface soil was more in the FYM alone treated plot $\left(\mathrm{T}_{2}\right)$ (0.53 per cent) as compared to rest of the treatments ( 0.28 per cent to 0.39 per cent) This might be due to the supply of organic matter through application of FYM to the soil @ $5 \mathrm{t} \mathrm{ha}^{-1}$ once in three years continuously for the last 34 years.

\section{Free calcium carbonate $(\%)$}

The free calcium carbonate of surface soil ranged from 0.24 to 0.46 with a mean value of 0.33 . However, the highest significant value was observed in FYM alone treated plot $\left(\mathrm{T}_{2}\right)$ (0.46) which was on par with $\mathrm{K}$ alone treated plot $\left(\mathrm{T}_{5}\right)(0.45)$. Lowest value was observed in gypsum alone treated plot $\left(\mathrm{T}_{6}\right)(0.24)$ which was on par with $\mathrm{T}_{9}(0.26)$ (Table1).

With regard to sub surface soil, the free calcium carbonate was ranged from 0.19 to 0.43 . However highest value was recorded in FYM alone treated plot $\left(\mathrm{T}_{2}\right)(0.43)$ and lowest value was observed in gypsum alone treated plot ( $\left.\mathrm{T}_{6}\right)$ (0.19).In general, the alfisols of chittoor district had a low content of free lime. This was supported by Ranganayakulu et al., 1986 and Munaswamy et al., 1989.

\section{Major nutrients}

\section{Available nitrogen}

The available $\mathrm{N}$ of the surface soil was ranged from 140.3 to 184.6 with a mean value of 165.0. However, highest significant value was recorded in FYM alone treated plot $\left(\mathrm{T}_{2}\right)$ (184.6) which was on par with $\mathrm{N}$ alone treated plot $\left(\mathrm{T}_{3}\right)(181.4)$ whereas lowest was observed in control plot $\left(\mathrm{T}_{1}\right)(140.3)$.

In the sub surface soil available $\mathrm{N}$ ranged from 129.9 to 178.2 with a mean value of 157.5. However, highest significant value was recorded in FYM alone treated plot $\left(\mathrm{T}_{2}\right)$ (178.2) whereas lowest was observed in control plot $\left(\mathrm{T}_{1}\right)$ (129.9).

From the results (Table-2) it could be noticed that the available nitrogen was said to be low irrespective of the treatments studied as per the rating chart given by Muhr et al., (1965). The accumulation of higher amount of available nitrogen in the FYM treated plot as compared to other treatments might be due to supplying of FYM to the soil once in three years for the last 34 years. Similar results were also obtained by Babu et al., (2007).

\section{Available phosphorus}

The available phosphorus content of the surface soil ranged from 46.5 to 25.4 with a mean value of 38.3. However, significantly highest value was observed in $\mathrm{NPK}+$ gypsum $+\mathrm{ZnSO}_{4}\left(\mathrm{~T}_{11}\right)$ (46.5) which was on par with $\mathrm{T}_{8}$ (44.4), $\mathrm{T}_{2}$ (44.0), $\mathrm{T}_{10}$ (43.7), $\mathrm{T}_{5}$ (43.2) and $T_{9}$ (42.8) whereas lowest value was observed in control plot $\left(\mathrm{T}_{1}\right)$ (25.4). In the sub surface soil ranged from 24.7 to 41.6 with a mean value of 34.7. However, significantly highest value was observed in $\mathrm{NPK}+\mathrm{G}+\mathrm{ZnSO}_{4}\left(\mathrm{~T}_{11}\right)$ (41.6) which was on par with $\mathrm{T}_{8}$ (40.9), $\mathrm{T}_{10}$ (40.8), $\mathrm{T}_{9}$ (40.0), $\mathrm{T}_{2}$ (39.1) and $\mathrm{T}_{5}(36.5)$. 
Table.1 Soil physico-chemical properties of experimental field as influenced by long-term application of manure and fertilizers

\begin{tabular}{|c|c|c|c|c|c|c|c|c|}
\hline \multirow[t]{2}{*}{ Treatments } & \multicolumn{2}{|c|}{ pH } & \multicolumn{2}{|c|}{ Electrical conductivity $\left(\mathrm{dSm}^{-1}\right)$} & \multicolumn{2}{|c|}{ Organic carbon (\%) } & \multicolumn{2}{|c|}{ Free calcium carbonate (\%) } \\
\hline & $0-15 \mathrm{~cm}$ & $15-30 \mathrm{~cm}$ & $0-15 \mathrm{~cm}$ & $15-30 \mathrm{~cm}$ & $0-15 \mathrm{~cm}$ & $15-30 \mathrm{~cm}$ & $0-15 \mathrm{~cm}$ & $15-30 \mathrm{~cm}$ \\
\hline $\mathrm{T}_{1}$ Control & 5.61 & 5.50 & 0.05 & 0.05 & 0.39 & 0.29 & 0.37 & 0.30 \\
\hline $\mathrm{T}_{2}$ FYM@ $5 \mathrm{tha}^{-1}$ & 5.57 & 5.43 & 0.08 & 0.07 & 0.53 & 0.29 & 0.46 & 0.43 \\
\hline$T_{3} \mathbf{N} @ 20 \mathrm{~kg} \mathrm{ha}^{-1}$ & 5.44 & 5.39 & 0.05 & 0.04 & 0.40 & 0.28 & 0.29 & 0.28 \\
\hline $\mathrm{T}_{4} \mathrm{P} @ 10 \mathrm{~kg} \mathrm{ha}^{-1}$ & 5.39 & 5.36 & 0.04 & 0.07 & 0.34 & 0.25 & 0.36 & 0.30 \\
\hline $\mathrm{T}_{5} \mathrm{~K} @ 25 \mathrm{~kg} \mathrm{ha}^{-1}$ & 5.37 & 5.32 & 0.05 & 0.05 & 0.28 & 0.25 & 0.45 & 0.36 \\
\hline T. Gypsum @ $250 \mathrm{~kg} \mathrm{ha}^{-1}$ & 5.35 & 5.30 & 0.19 & 0.07 & 0.36 & 0.29 & 0.24 & 0.19 \\
\hline $\mathbf{T}_{7} \mathbf{N P}$ & 5.32 & 5.30 & 0.05 & 0.09 & 0.34 & 0.28 & 0.29 & 0.26 \\
\hline $\mathrm{T}_{8}$ NPK & 5.24 & 5.22 & 0.07 & 0.06 & 0.32 & 0.29 & 0.31 & 0.24 \\
\hline $\mathrm{T}_{9} \mathrm{NPK}+\mathrm{G}$ & 5.41 & 5.30 & 0.08 & 0.08 & 0.37 & 0.30 & 0.26 & 0.25 \\
\hline $\mathrm{T}_{10} \mathrm{NPK}+\mathrm{L}$ & 5.54 & 5.41 & 0.18 & 0.06 & 0.38 & 0.31 & 0.34 & 0.26 \\
\hline $\mathrm{T}_{11} \mathrm{NPK}+\mathrm{G}+\mathrm{ZnSO}_{4}$ & 5.44 & 5.33 & 0.12 & 0.06 & 0.32 & 0.30 & 0.31 & 0.29 \\
\hline SEm+ & 0.08 & 0.05 & 0.04 & 0.01 & 0.05 & 0.05 & 0.01 & 0.04 \\
\hline $\mathrm{CD}(\mathrm{P}=0.05)$ & NS & NS & NS & NS & NS & NS & 0.02 & NS \\
\hline
\end{tabular}

Table.2 Soil available macronutrients $\left(\mathrm{kg} \mathrm{ha}^{-1}\right)$ and secondary nutrients $(\mathrm{Ca}$ and $\mathrm{Mg}$ ) of experimental field at sowing as influenced by long-term application of manure and fertilizers

\begin{tabular}{|c|c|c|c|c|c|c|c|c|c|c|}
\hline \multirow[t]{2}{*}{ Treatments } & \multicolumn{2}{|c|}{ Nitrogen $\left(\mathrm{kg} \mathrm{ha}^{-1}\right)$} & \multicolumn{2}{|c|}{ Phosphorus (kg ha $\left.{ }^{-1}\right)$} & \multicolumn{2}{|c|}{ Potassium $\left(\mathrm{kg} \mathrm{ha}^{-1}\right)$} & \multicolumn{2}{|c|}{$\begin{array}{c}\text { Exchangeable } \\
\text { calcium }\left(\mathrm{cmol}(\mathrm{p}+) \mathrm{kg}^{-1}\right)\end{array}$} & \multicolumn{2}{|c|}{$\begin{array}{l}\text { Exchangeable Magnesium } \\
\qquad\left(\mathrm{cmol}(\mathrm{p}+) \mathrm{kg}^{-1}\right)\end{array}$} \\
\hline & $0-15 \mathrm{~cm}$ & $15-30 \mathrm{~cm}$ & $0-15 \mathrm{~cm}$ & $15-30 \mathrm{~cm}$ & $0-15 \mathrm{~cm}$ & $15-30 \mathrm{~cm}$ & $0-15 \mathrm{~cm}$ & $15-30 \mathrm{~cm}$ & $0-15 \mathrm{~cm}$ & $15-30 \mathrm{~cm}$ \\
\hline $\mathrm{T}_{1}$ Control & 140.3 & 129.9 & 25.4 & 26.6 & 170.35 & 102.15 & 2.32 & 3.38 & 1.80 & 1.86 \\
\hline $\mathrm{T}_{2}$ FYM@ $5 \mathrm{tha}^{-1}$ & 184.6 & 178.2 & 44.0 & 39.1 & 157.95 & 94.92 & 3.11 & 3.58 & 2.45 & 2.48 \\
\hline $\mathrm{T}_{3} \mathrm{~N} @ 20 \mathrm{~kg} \mathrm{ha}^{-1}$ & 181.4 & 170.5 & 32.4 & 27.8 & 181.72 & 136.59 & 3.29 & 3.46 & 2.21 & 2.24 \\
\hline $\mathrm{T}_{4} \mathrm{P} @ 10 \mathrm{~kg} \mathrm{ha}^{-1}$ & 157.7 & 158.4 & 36.7 & 33.2 & 147.39 & 100.60 & 2.98 & 3.50 & 2.02 & 2.08 \\
\hline $\mathrm{T}_{5} \mathrm{~K} @ 25 \mathrm{~kg} \mathrm{ha}^{-1}$ & 153.9 & 143.5 & 43.2 & 36.5 & 312.43 & 253.54 & 3.37 & 3.59 & 1.97 & 2.03 \\
\hline $\mathrm{T}_{6}$ Gypsum @ $250 \mathrm{~kg} \mathrm{ha}^{-1}$ & 156.7 & 154.2 & 27.0 & 24.7 & 135.35 & 99.71 & 4.39 & 4.56 & 1.92 & 1.97 \\
\hline $\mathrm{T}_{8} \mathrm{NPK}$ & 169.6 & 159.1 & 44.4 & 40.9 & 187.88 & 126.98 & 3.08 & 3.43 & 2.67 & 2.70 \\
\hline $\mathrm{T}_{9} \mathrm{NPK}+\mathrm{G}$ & 165.7 & 154.7 & 42.8 & 40.0 & 227.28 & 104.35 & 3.98 & 4.16 & 2.30 & 2.37 \\
\hline $\mathrm{T}_{10} \mathrm{NPK}+\mathrm{L}$ & 169.2 & 164.4 & 43.7 & 40.8 & 203.67 & 135.52 & 3.52 & 4.10 & 2.14 & 2.16 \\
\hline $\mathrm{T}_{11} \mathrm{NPK}+\mathrm{G}+\mathrm{ZnSO} 4$ & 173.4 & 166.2 & 46.5 & 41.6 & 178.67 & 97.69 & 3.96 & 4.20 & 2.41 & 2.52 \\
\hline SEm+ & 3.83 & 2.15 & 2.23 & 2.02 & 3.62 & 1.60 & 0.02 & 0.29 & 0.22 & 0.30 \\
\hline $\mathrm{CD}(\mathrm{P}=0.05)$ & 11.10 & 6.24 & 6.48 & 5.85 & 10.51 & 4.65 & 0.03 & NS & NS & NS \\
\hline
\end{tabular}

Note: $\mathrm{G}=$ Gypsum, L=Lime @ $100 \mathrm{~kg} \mathrm{ha}^{-1}, \mathrm{ZnSO}_{4} @ 25 \mathrm{~kg} \mathrm{ha}^{-1}$ 
The accumulation of considerable amount of available phosphorus in the treatment NPK + gypsum $+\mathrm{ZnSO} 4\left(\mathrm{~T}_{11}\right)$ both in the surface $\left(46.5 \mathrm{~kg} \mathrm{ha}^{-1}\right)$ and sub-surface (41.6 kg ha-1) soil as compared to rest of the treatments might be due to the blocking of available phosphorus which lead to formation of tricalcium phosphate. The formation of tricalcium phosphate might be due to presence of considerable amount of calcium in the soil. Large buildup of available phosphorus in the fertilizer and manurial treatments under long-term experiment on groundnut crop was also reported by Srinivasarao et al., (2013).

\section{Available potassium}

The available potassium content of surface soil was ranged from 135.35 to 312.43 with a mean value of 185.40. However, highest significant value was observed in $\mathrm{K}$ alone treated plot $\mathrm{T}_{5}$ (312.43) whereas lowest significant value was observed in gypsum alone treated plot $\left(\mathrm{T}_{6}\right)(135.35)$.

In the sub surface soil was ranged from 86.21 to 253.54 with a mean value of 121.66. However, highest significant value was observed in $\mathrm{K}$ alone treated plot $\left(\mathrm{T}_{5}\right)$ (253.54) whereas lowest significant value was observed in NP $\left(\mathrm{T}_{7}\right)(86.21)$.

The results (Table-2) indicated that the available-K content was said to be medium to high in surface soil and low to medium in the sub surface soil as per the rating chart suggested by Muhr et al., (1965).

The buildup of soil available potassium in the $\mathrm{K}$ alone treated plot and $\mathrm{K}$ inclusive fertilizer combinations might be due to the additional potassium applied since long time in the longterm manurial and fertilizer trial. Similar results were also reported by Singh et al., (2009) and Babu et al., (2007).

\section{Exchangeable Calcium}

The exchangeable calcium of the surface soil was ranged from 2.32 to 4.39 with a mean value of 3.37. However, highest significant value was observed in gypsum alone treated plot $\left(\mathrm{T}_{6}\right)$ (4.39). The next best treatment was observed in NPK $+\mathrm{G}\left(\mathrm{T}_{9}\right)$ (3.98) which was on par with $\mathrm{T}_{11}$ (3.96) whereas the lowest value was observed in control plot $\left(\mathrm{T}_{1}\right)$ (3.38). In The sub surface soil was ranged from 4.56 to 3.38. However, highest value was observed in gypsum alone treated plot $\left(\mathrm{T}_{6}\right)$ (4.56) whereas the lowest value was observed in control plot $\left(\mathrm{T}_{1}\right)$ (3.38). In general, exchangeable calcium was relatively higher in the surface soil as compared to that of sub surface soil.

The exchangeable calcium both in the surface and sub-surface from the table- 2 was said to be high as per the limits suggested by Pasricha and Sarkar (2002). The higher value of exchangeable calcium in gypsum alone treated plot both in surface and sub-surface soil might be due to continuous application of gypsum @ of $250 \mathrm{~kg} \mathrm{ha}^{-1}$ for the last 34 years. These results were in conformity with findings of Babu et al., (2008).

\section{Exchangeable Magnesium}

The exchangeable magnesium in surface soil ranged from 1.80 to 2.74 . However, highest value was observed in NP treated plot $\left(\mathrm{T}_{7}\right)$ (2.74) whereas lowest value was observed in control plot $\left(\mathrm{T}_{1}\right)$ (1.80). The exchangeable magnesium in sub surface soil ranged from 1.86 to 3.01 (Table 3 ).

However highest value was observed in NP treated plot $\left(\mathrm{T}_{7}\right)$ (3.01) whereas the lowest value was observed in control plot $\left(\mathrm{T}_{1}\right)(1.86)$. The higher exchangeable magnesium was recorded in $\mathrm{K}$ inclusive fertilizer combinations and similar results were reported by Nathiya and Sanjiv, (2015). 
The present study revealed that the long-term application of fertilizers and manure improved the soil physico-chemical and chemical properties. Over a period of time, depletion of the nutrients was observed in the control, whereas, the application of manure and fertilizers has maintained good soil health and nutrients in soil in sustainable manner there by to achieve higher yields.

\section{Acknowledgements}

The author is highly grateful to the Acharya N.G. Ranga Agricultural University for providing financial assistance in the form of stipend during the course of this investigation.

\section{References}

Annual Report 2014-15, ICAR-Directorate of Groundnut Research, Junagadh362001, Gujarat, India.

Babu, K.G., Munaswamy, V and Padma Raju, A. 2007. Effect of long-term application of manure and fertilizers on yield and yield attributes of rainfed groundnut (Arachis hypogaea L.). Journal of oilseeds Research. 24(2): 326-327.

Babu, K.G., Munaswamy, V and Padma Raju, A. 2008. Influence of manure and fertilizers on soil available secondary nutrients at different growth stages of groundnut in an Alfisols. Mysore Journal of Agricultural Science. 42(1): 38-45.

Bhaskara, N.R., Ranganayakulu, C., Seshagirirao, M., Rajareddy, C.K., Srinivasareddy, C.K and Venkaiah, K. 1992. Long term effects of manure and fertilizers on composition and uptake of nutrients by rainfed groundnut (Arachis hypogaea L.) with reference to yield, nitrogen, phosphorus and potassium. New Botanist. 9: 169-175.

Brar, B.S., Singh, J., Singh, G and Kaur, G. 2015. Effects of long term application of inorganic and organic fertilizers on soil organic carbon and physical properties in maize-wheat rotation. Agronomy. 5(2): 220-238.

Hemalatha, S and Chellamuthu, S. 2013. Impacts of long-term fertilization on soil nutritional quality under finger millet; maize cropping sequence. Journal of Environmental and Research. 7(4A): 1571-1576.

Jackson, M.L. 1973. Soil chemical analysis.Prentice Hall of India Private Limited, New Delhi.

Lakshmi, G.V., Prasad, P.R.K., Babu, P.R., Rao, V.S., Babu, M.R., Krishna, V.R., Latha, M., Hema, K., Gupta, S.K and Ambast, S.K. Ground water quality of Andhra Pradesh. 2013. AICRP-Saline water scheme, Bapatla. Pp-2.

Muhr, G.R., Datta, N.P., Sankrasubramoney, H., Leley, V.V and Donahue, R.L. 1965. Soil testing in India. USAID, New Delhi, 120p.

Munaswamy, V., Rao, S.I.V. and Prasad, R.B. 1989.A study on nutrients status of groundnut growing soils of Chittoor district. The Andhra Agricultural Journal. 36 (4): 287-291.

Nathiya, K.V and Kumar, V.S. 2015. Dynamics of potassium by the combined use of organic manures and inorganic potassium fertilizers on available nutrients of groundnut crop (Arachis hypogea) in Madukkur soil series. Journal of Applied and Natural Science. 7(1): 197-202.

Panse, V.G and Sukhatme, P.V. 1985. Statistical metods for agricultural workers. Indian Council of Agricutural Research, New Delhi.

Pasricha and Sarkar. 2002. Secondary nutrients in Fundamental of Soil Science, edited by goswami et al., 2009. Indian Society of Soil Science, New Delhi, pp-449-460. 
Piper, C.S. 1966. Soil and Plant Analysis. Hans Publications, Bombay.pp. 59.

Ranganayakulu, C., Prasad Rao, D.M.V., Padma Raju, A., SreenivasaMoorthy, V.V.M., Prabhu, M.R.L and SankaraReddi, G.H. 1986. Distribution of zinc and copper in Typical Alfisols profiles and surface soils of Chittoor district. The Andhra Agricultural Journal.33: 335-342.

Richards, L.A., Allison, L.E and Borhestein. 1954. Diagnosis and improvement of saline and alkali soils. Oxford and IBH Publishing Company, New Delhi.

Singh, A.K., Sarkar, A.K., Kumar, A and Singh, B.P. 2009. Effect of long-term use of mineral fertilizers, lime and farm yard manure on the crop yield, available plant nutrient and heavy metal status in an acidic loam soil. Journal of the Indian Society of Soil Science. 57(3): $362-365$.

Srinivasarao, Ch., Sumanta, K., Venkateswarlu, B., Lal, R., Singh, A.K., Balaguravaiah, G., Vijayasankarbabu, M., Vittal, K.P.R., Reddy, $\mathrm{S}$ and
Manideep, V.R. 2013. Long-term effect of fertilization and manuring on groundnut yield and nutrient balance of Alfisols under rainfed farming in India. Nutrient Cycling in Agroecosystems. 96: 29-46.

Subbiah, B.V and Asija, G.L. 1956. A rapid method for estimation of available nitrogen in soil.Current Science.25: 258-260.

Urkurkar, J.S., Tiwari, A., Chitale, S and Bajpai, R.K. 2010. Influence of longterm use of oraganic and inorganic manure on soil fertility and sustainable productivity of rice (Oryza sativa) and wheat (Triticum aestivum) in Inceptisols. Indian Journal of Agricultural Sciences. 80(3): 208-212.

Vogel, A.I. 1978. A text book of quantitative inorganic analysis. Richard clay (The Chancer Press) Limited, Britain.

Walkley, A and Black, A.I. 1934. An examination of soil organic matter and proposed modification of the organic acid titration method. Soil Science.37: 29-38.

\section{How to cite this article:}

Shivashankar C., A. Prasanthi, K. V. Naga Madhuri and Sunitha N. 2018. Long-Term Effect of Manure and Fertilizers on Soil Physico-Chemical and Chemical Properties in Rainfed Groundnut Growing Alfisols. Int.J.Curr.Microbiol.App.Sci. 7(06): 2043-2050.

doi: https://doi.org/10.20546/ijcmas.2018.706.241 